\title{
Genetic analysis of $\mathrm{NaCl}$ tolerance in tomato
}

\author{
A. Saeed ${ }^{1}$, M.Q. Shahid ${ }^{2}$, S.A. Anjum ${ }^{3}$, A.A. Khan $^{1}$, A. Shakeel ${ }^{1}$, \\ M.F. Saleem ${ }^{4}$ and N. Saeed ${ }^{5}$ \\ ${ }^{1}$ Department of Plant Breeding and Genetics, University of Agriculture, \\ Faisalabad, Pakistan \\ ${ }^{2}$ Guangdong Provincial Key Laboratory of Plant Molecular Breeding, \\ South China Agricultural, Guangdong, China \\ ${ }^{3}$ College of Agronomy and Biotechnology, Southwest University, \\ Chongqing, China \\ ${ }^{4}$ Department of Agronomy, University of Agriculture, Faisalabad, Pakistan \\ ${ }^{5}$ Department of Mathematics and Statistics, University of Agriculture, \\ Faisalabad, Pakistan
}

Corresponding author: A. Saeed

E-mail: drasifpbg@gmail.com

Genet. Mol. Res. 10 (3): 1754-1776 (2011)

Received December 7, 2010

Accepted June 8, 2011

Published August 23, 2011

DOI http://dx.doi.org/10.4238/vol10-3gmr1198

\begin{abstract}
We attempted to find the suitable parents for the development of tomato hybrids for high salt soils by exploiting combining ability, gene action and heterosis. Six salt-tolerant and three salt-intolerant genotypes, along with their $18 \mathrm{~F} 1$ crosses, were evaluated at seedling stage under 10 and $15 \mathrm{dS} / \mathrm{m}(\mathrm{NaCl})$ salinity stress, compared to the control level of salinity. The experiment was laid out based on a two-way complete randomized design factorial arrangement with two replications; data on root and shoot length, fresh and dry weights, leaf
\end{abstract}


area, plant length, $\mathrm{Na}^{+}, \mathrm{K}^{+}$and $\mathrm{K}^{+} / \mathrm{Na}^{+}$concentrations were recorded. There was significant variation within genotypes, lines, testers, crosses, and line $\times$ tester interaction for all plant characters studied under normal and two salinity levels. Estimates of combining ability indicated that under low $(10 \mathrm{dS} / \mathrm{m})$ and high $(15 \mathrm{dS} / \mathrm{m})$ salinities, line BL1176 and tester LO2875 showed significant GCA effects for most of the traits studied. The cross-combinations $6233 \times$ LO2875, CLN2498A $x$ LO2875 and BL1176 $\times 17902$ showed highest SCA values for most of the characters under 10 and $15 \mathrm{dS} / \mathrm{m}$, respectively. Potence ratio showed that under low and high salinities, all the traits showed over dominant type of gene action except leaf area and $\mathrm{K}^{+}$concentration (in $10 \mathrm{dS} / \mathrm{m}$ ) and shoot length, and leaf area (in $15 \mathrm{dS} / \mathrm{m}$ ). The highest heterosis for most of the parameters was observed in cross-combinations BL1176 $\times$ LO2875 and CLN2498A x LO2875.

Key words: Salinity; Tomato; Seedlings; Line x tester analysis; Combining ability; Heterosis

\section{INTRODUCTION}

Salt stress is a major challenge to plants as it limits crop production all over the world, particularly on irrigated farmlands (Rausch, 1996). The impact of salinity has become more important due to increasing amounts of land becoming salinized due to poor irrigation practices (Winicov, 1998). Plants in natural environments are being constantly exposed to increasing amounts of salinity. One-third of the irrigated land worldwide is affected by salinity but salinity also occurs in non-irrigated land (Allen et al., 1994). The term salt-affected refers to soils that are saline or sodic, and these cover over $400 \mathrm{~m} / \mathrm{ha}$, which is $6 \%$ of the world land area. Of the current $230 \mathrm{~m} / \mathrm{ha}$ irrigated land, $45 \mathrm{~m} / \mathrm{ha}$ are salt-affected (19.5\%), and of the $1500 \mathrm{~m} / \mathrm{ha}$ under dry land agriculture, $32 \mathrm{~m} / \mathrm{ha}(2.1 \%)$ are salt-affected to varying degrees (Munns, 2002).

However, the problem of salinity can be tackled by various techniques. Rehabilitation of the salt-affected wasteland can be accomplished by adopting reclamation measures involving physical, chemical and hydrological approaches. Many of these soils are beyond the reach of conventional reclamation techniques, either for economic reason or for lack of fresh water. A major possibility, which appears to be more feasible, is the development of crop cultivars suitable for the areas affected by salinity, called the "biological/genetic approach". This approach is cheaper, and has been emphasized by many authors (Qureshi et al., 1990; Hollington, 1998). Saline agriculture is another concept of generating income by using saline lands without spending huge amount of funds on drainage and reclamation work. This approach had been demonstrated successfully by planting economically important salt tolerant trees and shrubs, e.g., Atriplex and Eucalyptus on-farm trials in areas affected by salinity (Qureshi, 1993). Moreover, improvement in salt tolerance in different plant species could be possible through selection and breeding. 
The success of developing salt-tolerant plant material, through selection and genetic modification, depends on the existence of heritable variation within the crop species in response to salt stress. There is ample information reported on salt tolerance, which reveals that variability in salinity tolerance does exist both between and within plant species, e.g., tomato (Hassan et al., 1999; Shaaban et al., 2004), wheat (Sarwar et al., 2003), rice (Gain et al., 2004), and other crop plants. This variability can be exploited for the production of newer and higher yielder cultivars and hybrids. Hence, there is a need to utilize a huge acreage of wastelands for agricultural purposes, and certainly, cultivation of crops in the areas affected by salinity would contribute towards increasing production. Therefore, the present study has undertaken in order to identify suitable breeding procedures facilitating the way forward for the development of tomato genotypes suitable for salt affected regions.

\section{MATERIAL AND METHODS}

Six salt tolerant LA2661, CLN2498A, CLN1621L, BL1176, 6233, 17870, and three non-tolerant accessions 17902, LO2875 and LO4360 were grown in the field. At the time of flowering, crosses were made exploiting a line $\mathrm{x}$ tester mating design (Kempthorne, 1957) keeping six tolerant parents as females (lines) and three susceptible parents as males (testers). At the time of maturity, tomato fruits were harvested in bags. The selfed and crossed fruits were crushed and then fermented. Seeds were washed by careful removal of floating pieces of flesh and skin. The container was inclined and the floating refuse was gently removed. Washing was repeated several times by adding fresh water to the container each time until all the flesh and gel were completely removed, leaving clean seeds at the bottom. In order to determine the inheritance pattern of salt tolerance in tomato, seeds of $\mathrm{F}_{1}$ crosses along with parents were sown in sand culture and saline water was applied to develop a salinity level of 10 and $20 \mathrm{dS} / \mathrm{m}$ while normal tap water was used for irrigation in control treatment. Thus, the experiment was laid out in a 2-factor completely randomized design arrangement.

The seedlings were separated into roots and shoots with a sharp blade. Root length was measured with the help of a scale in centimeters. Shoots were also measured in the same way. Fresh roots and shoots were weighed after blotted dry. After taking the fresh weight, roots and shoots were placed separately in Kraft paper bags and were placed in the oven for drying at $80^{\circ} \mathrm{C}$ for constant dry weight and the average dry root and shoot weights were calculated. Fresh root and shoot length were added to obtain plant length. Leaf area was calculated by multiplying the primary leaf length $(\mathrm{cm})$ and width $(\mathrm{cm})$. In order to study the concentration of $\mathrm{Na}^{+}$and $\mathrm{K}^{+}$, fully expanded leaves of each genotype grown under stress and non-stress conditions were taken. These samples were stored for 1 week and concentrations of $\mathrm{Na}^{+}$and $\mathrm{K}^{+}$were determined using flame photometer. $\mathrm{K}^{+} / \mathrm{Na}^{+}$ratio was calculated using the values of $\mathrm{Na}^{+}$and $\mathrm{K}^{+}(\mathrm{mM})$.

The data of all the traits were analyzed using analysis of variance technique (Steel et al., 1997) in order to see the significance of genotypic responses to salinity. The characters showing significant genotypic differences were further subjected to "line x tester" analysis as outlined by Kempthorne (1957) to obtain the information about gene action, general combining ability (GCA), specific combining ability (SCA). Percent heterosis over better parent (heterobeltiosis) was calculated using formulae proposed by Falconer and Mackay (1996) and presented as follows: 
Percent heterosis over better parent $(\mathrm{BP})=\left\{\left(\mathrm{F}_{1}-\mathrm{BP}\right) / \mathrm{BP}\right\} \times 100$.

The $t$-test was applied (Wynne et al., 1970) to test the significance of heterosis over better parents as given by: $\mathrm{t}($ static $)=\left\{\left(\mathrm{F}_{1}-\mathrm{BP}\right) /(1 / 2 \mathrm{MSE})^{1 / 2}\right\}$.

\section{RESULTS}

Ordinary analysis of variance of absolute data showed highly significant differences among all the genotypes including parents and hybrids for various morpho-physiological parameters, i.e., root length, shoot length, fresh root weight, fresh shoot weight, dry root weight, dry shoot weight, leaf area, plant length, $\mathrm{K}^{+}$concentration, $\mathrm{Na}^{+}$concentration, and $\mathrm{K}^{+} / \mathrm{Na}^{+}$ratio (Table 1 ). The three levels of $\mathrm{NaCl}$ salinity were statistically different for all traits. The interaction (accession $\mathrm{x}$ concentration) was highly significant for all traits indicating that all genotypes (parents and hybrids) responded differently to low and high salinities.

Formal analysis of variance of the absolute data portioned the treatments into parents, crosses, parents $v s$ crosses, and parents were further portioned into lines, tester and line $\mathrm{x}$ tester (Tables 2, 3, 4). It showed that differences among treatment were significant for all traits. The variance due to parents was significant for all the traits in control, low and high salinities. The interaction parents $v s$ crosses was significant for all the traits except fresh root weight in control while it was significant for all the traits in low $(10 \mathrm{dS} / \mathrm{m})$ and high salinities $(20 \mathrm{dS} / \mathrm{m})$. The variance due to crosses was found to be significant for all the traits in control and $10 \mathrm{dS} / \mathrm{m}$. Variance due to lines and testers was also significant for all the traits, i.e., root length, shoot length, fresh root weight, fresh shoot weight, dry root weight, dry shoot weight, leaf area, plant length, $\mathrm{K}^{+}$concentration, $\mathrm{Na}^{+}$concentration, and $\mathrm{K}^{+} / \mathrm{Na}^{+}$ratio in low $(10 \mathrm{dS} / \mathrm{m})$ and high salinity $(20 \mathrm{dS} / \mathrm{m})$ levels. Interaction lines $\mathrm{x}$ tester appeared to be significant for all the traits in control and $10 \mathrm{dS} / \mathrm{m}$, except shoot length, which is non-significant in high salinity (20 dS/m).

General combining ability effects of lines and testers under control level (Table 5) indicated that among the lines, CLN2498A showed maximum and significant SCA effects for dry root weight and $\mathrm{Na}^{+}$uptake. Line BL1176 exhibited maximum GCA effects for root length, fresh shoot weight, dry shoot weight, leaf area, and $\mathrm{K}^{+}$uptake, while line 6233 showed maximum and significant GCA effects for shoot length, plant length and $\mathrm{K}^{+} / \mathrm{Na}^{+}$ratio. In GCA of the tester, 17902 showed the desirable significant effects for fresh root weight, dry shoot weight, leaf area, and $\mathrm{Na}^{+}$concentration and significant GCA effects were also indicated by the tester LO2875 for the traits, i.e., root length, fresh shoot weight, dry root weight, $\mathrm{K}^{+}$concentration, and $\mathrm{K}^{+} / \mathrm{Na}^{+}$ratio.

Under $10 \mathrm{dS} / \mathrm{m}$ salinity stress (Table 6), line BL1176 had significant GCA effects for all the traits except fresh root weight, dry root weight and $\mathrm{Na}^{+}$concentration, while among testers, LO2875 exhibited the highest and significant GCA effects for root length, shoot length, fresh shoot weight, dry root weight, plant length, $\mathrm{Na}^{+}$concentration, and $\mathrm{K}^{+} / \mathrm{Na}^{+}$ratio. Line CLN2498A had significant GCA effects for two traits, i.e., fresh root weight and dry root weight, while tester 17902 showed the significant GCA effects for fresh root weight, dry shoot weight and leaf area. Under high salinity stress $(15 \mathrm{dS} / \mathrm{m})$, line BL1176 again had significant GCA effects for all the traits except root length, fresh root weight and dry root weight, whereas line CLN2498A exhibited the significant GCA effects for only two traits, i.e., root length and dry root weight (Table 7). Among testers, 17902 showed significant effects for fresh root weight, dry shoot weight, leaf area, and $\mathrm{Na}^{+}$concentration, whereas tester LO2875 had the 


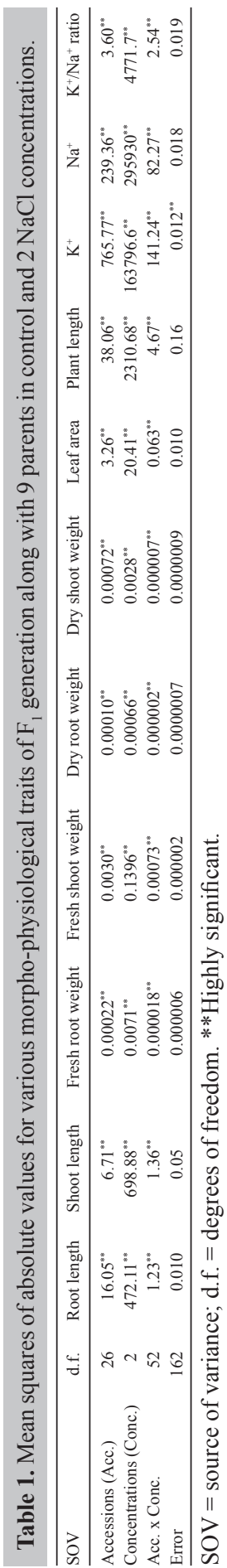




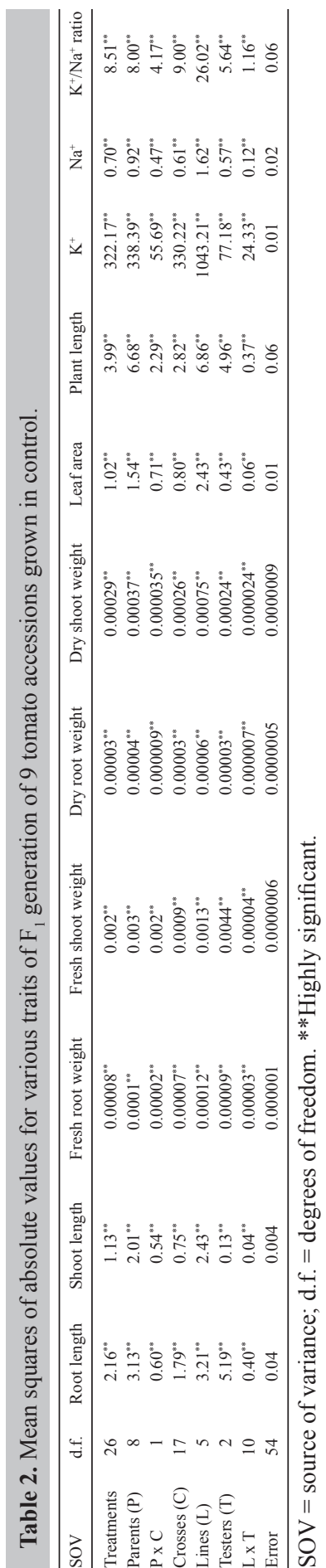




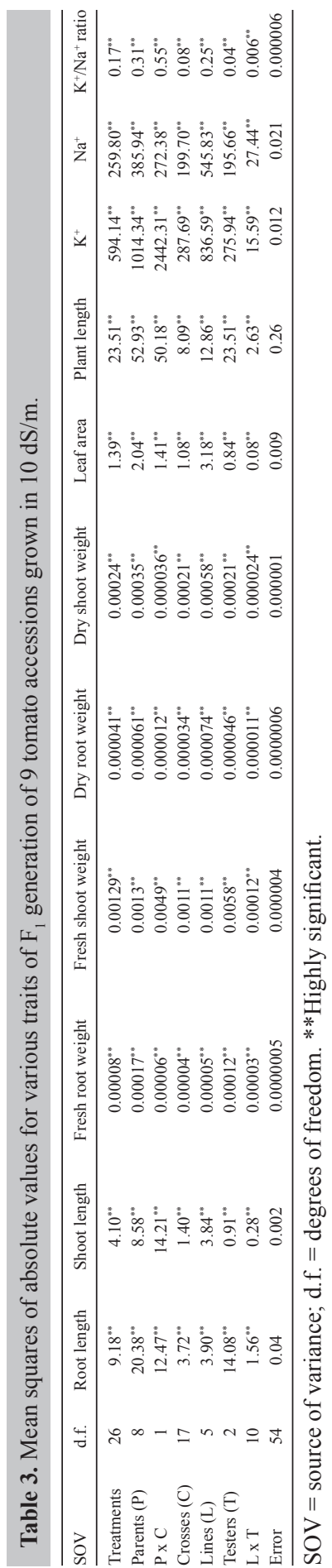




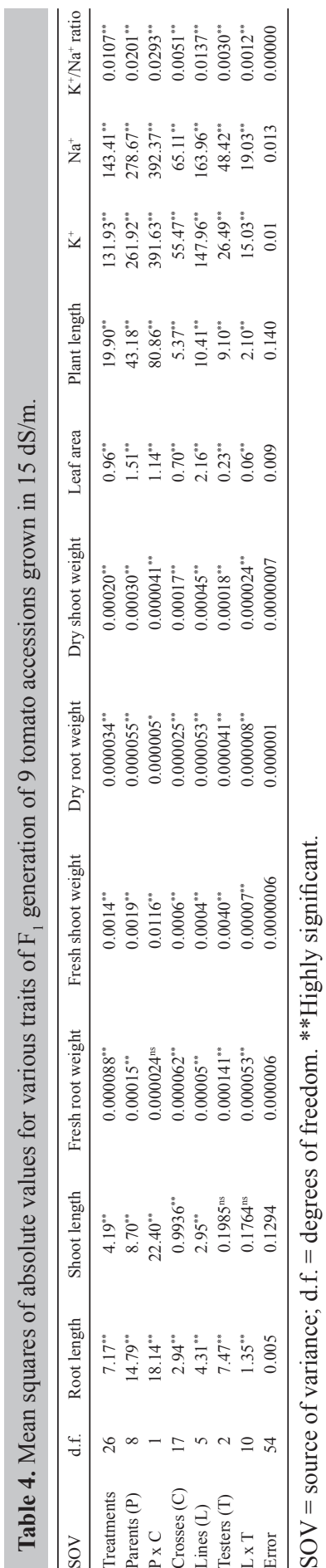


A. Saeed et al.

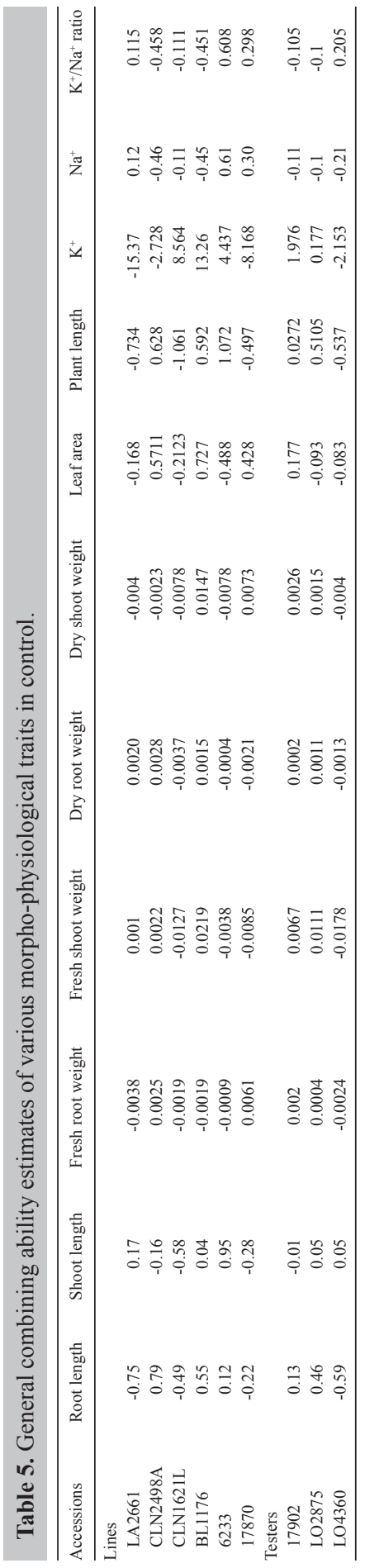




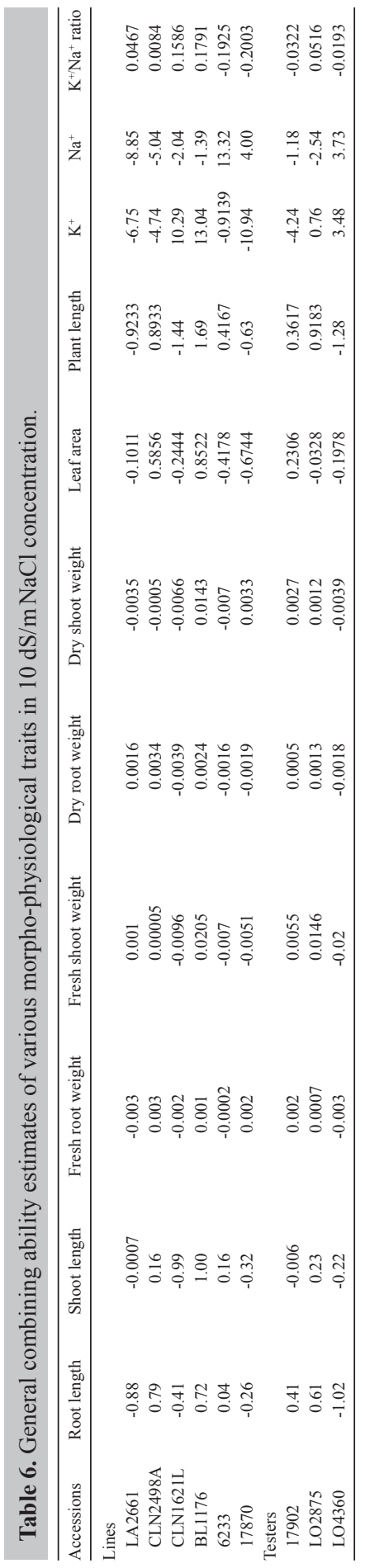


A. Saeed et al.

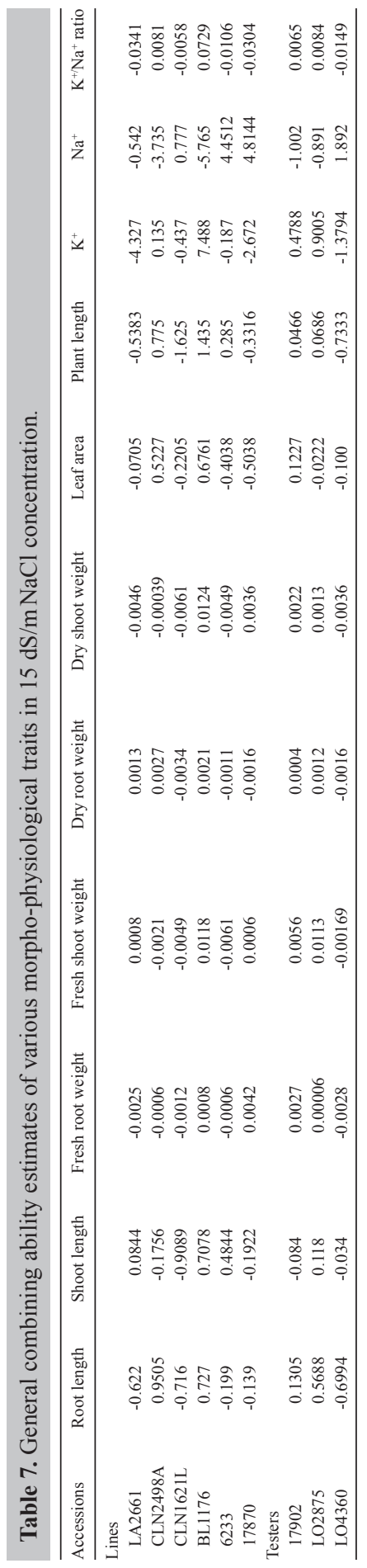


highest and significant GCA effects for root length, fresh shoot weight, dry root weight, $\mathrm{K}^{+}$ concentration, and $\mathrm{K}^{+} / \mathrm{Na}^{+}$ratio.

Estimates of SCA effects (Table 8) showed that under control conditions, crosscombination BL1176 x 17902 exhibited maximum significant SCA effects for root length, plant length, $\mathrm{Na}^{+}$concentration, and $\mathrm{K}^{+} / \mathrm{Na}^{+}$ratio, while for shoot length, fresh root weight, fresh shoot weight, dry root weight, dry shoot weight, leaf area, and $\mathrm{K}^{+}$, the hybrids CLN2498A x LO4360 exhibited maximum SCA effects.

In $10 \mathrm{dS} / \mathrm{m}$ salinity stress (Table 9), cross-combination 6233 x LO2875 showed maximum SCA effects for fresh root weight, fresh shoot weight and $\mathrm{K}^{+}$concentration, while the hybrid CLN2498A x LO2875 exhibited the highest SCA effects for shoot length, dry root weight and $\mathrm{K}^{+}$concentration. For root length, dry shoot weight, plant length, $\mathrm{Na}^{+}$concentration, and $\mathrm{K}^{+} / \mathrm{Na}^{+}$ratio, maximum SCA effects were found in cross-combinations CLN1621L x LO4360, 17870 x 17902, BL1176 x LO4360, 6233 x LO4360, and 17870 x LO4360, respectively.

In $15 \mathrm{dS} / \mathrm{m}$ salinity stress (Table 10), maximum SCA effects were observed, for root length, dry shoot weight, plant length, $\mathrm{Na}^{+}$concentration, and $\mathrm{K}^{+} / \mathrm{Na}^{+}$ratio, in cross-combination BL1176 $\times 17902$. While for shoot length, fresh root weight, fresh shoot weight, dry root weight, leaf area, and $\mathrm{K}^{+}$concentration, the highest SCA effects were found in hybrid combinations CLN2498A $\times$ LO2875, $17870 \times$ LO4360, BL1176 $\times$ LO4360, 6233 $\times$ LO4360, LA2661 $\times 17902$, and CLN2498A $\times 17902$, respectively.

Dominance variance, additive variance and potency ratio for various traits in tomato, by using absolute data, are presented in Table 11. In control, root length, fresh root weight, dry root weight, dry shoot weight, plant length, $\mathrm{Na}^{+}$concentration, and $\mathrm{K}^{+} / \mathrm{Na}^{+}$ ratio had over dominant type of gene action while the other traits, i.e., shoot length, fresh shoot weight, leaf area, and $\mathrm{K}^{+}$concentration showed partial dominant gene action. In low $(10 \mathrm{dS} / \mathrm{m})$ and high $(15 \mathrm{dS} / \mathrm{m})$ salinities, all traits showed over dominant type of gene action except leaf area and $\mathrm{K}^{+}$concentration in $10 \mathrm{dS} / \mathrm{m}$ and shoot length and leaf area in 15 $\mathrm{dS} / \mathrm{m}$, which exhibited partial dominant gene action.

Estimates of heterosis based upon absolute values of salt tolerance for various plant traits were made. In control (Table 12), maximum heterosis over better parent for root length was found in cross-combinations 17870 x LO2875 and 17870 x 17902 . For shoot length, hybrid CLN1621L x 17902 showed maximum heterosis followed by CLN2498A x 17902. Only hybrid CLN1621L x 17902 exhibited significant heterosis for fresh root weight. No significant and positive heterosis was observed for fresh shoot weight. Positive and significant heterosis was observed in cross-combinations LA2661 x 17902, CLN2498A x 17902, CLN2498A x LO2875 for dry root weight (Table 12). For dry shoot weight hybrids, $17870 \mathrm{x}$ 17902 and CLN2498A x LO2875 exhibited the significant and positive heterosis. Maximum heterosis was recorded for leaf area in hybrids CLN2498A x 17902, CLN2498A x LO2875 and BL1176 x 17902. The cross CLN1621L x 17902 showed significant heterosis for plant length. For $\mathrm{K}^{+}$concentration cross-combinations BL1176 x 17902 and BL1176 x LO2875 showed positive and significant heterosis. All traits showed negative heterosis for $\mathrm{Na}^{+}$concentration except the hybrid $6233 \times 17902$ (Table 12). Positive and significant heterosis was observed for $\mathrm{K}^{+} / \mathrm{Na}^{+}$ratio in cross-combination BL1176 x 17902.

In $10 \mathrm{dS} / \mathrm{m}$ (Table 13), three hybrids showed significant heterosis for root length. Maximum heterosis was observed in hybrid LA2661 x LO2875 followed by cross-combination LA2661 x 17902. For shoot length, five hybrids exhibited significant heterosis and 


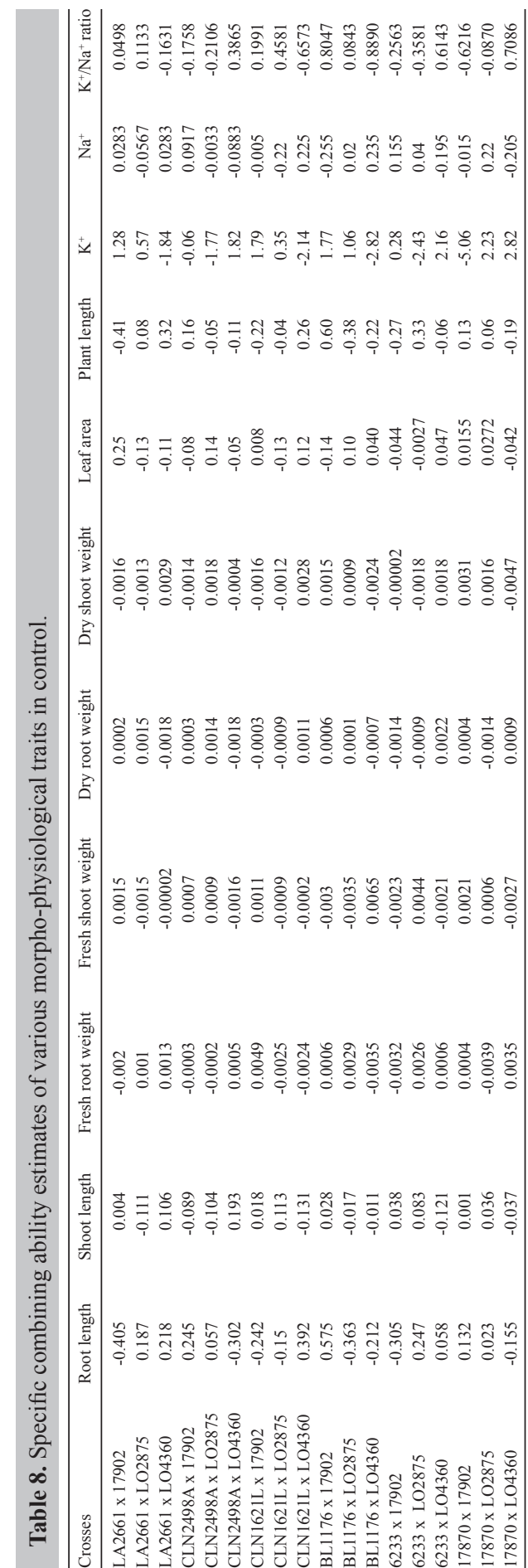




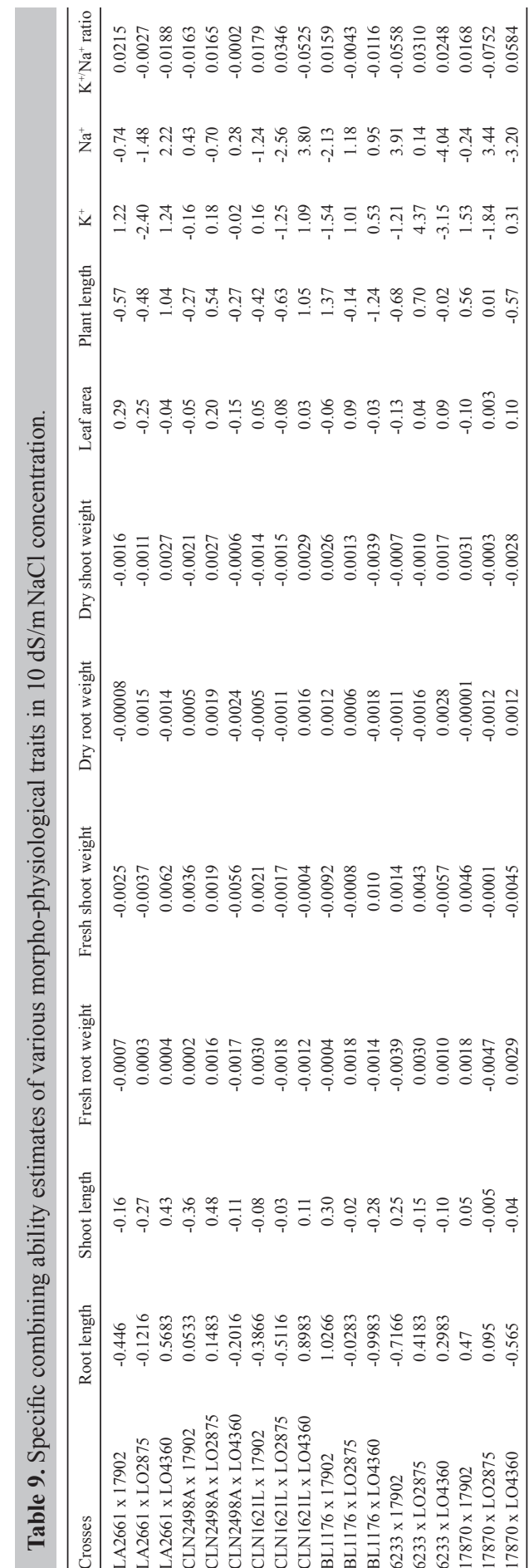




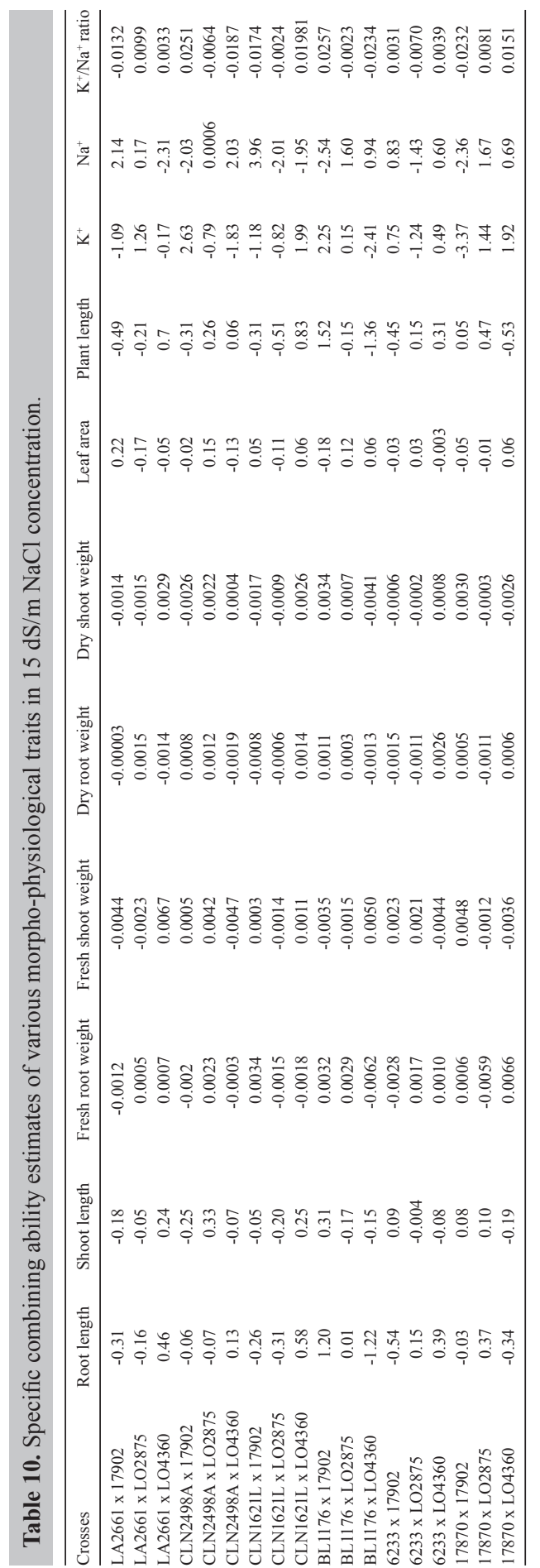




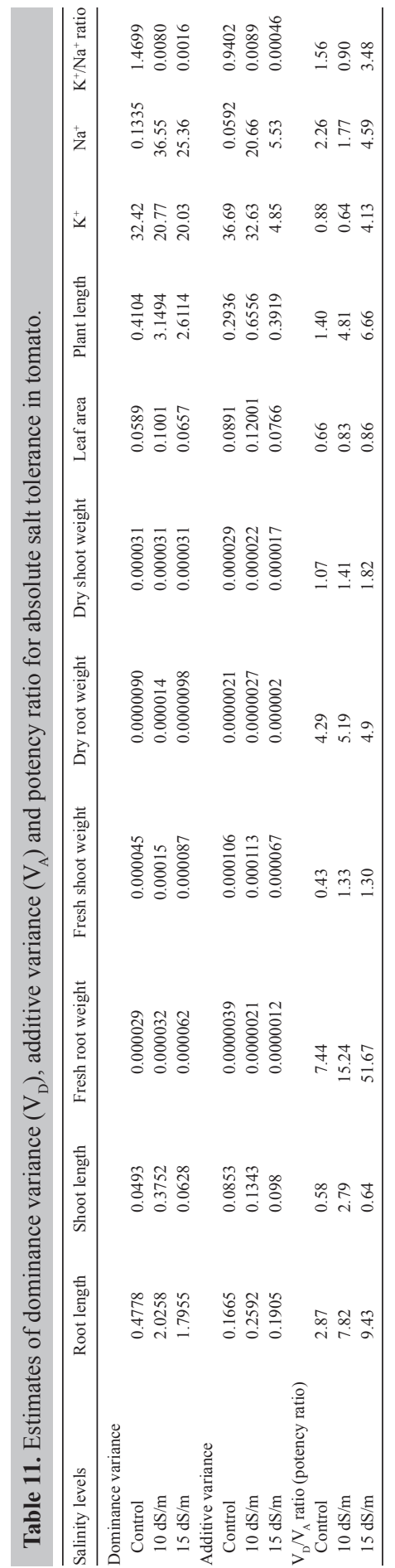




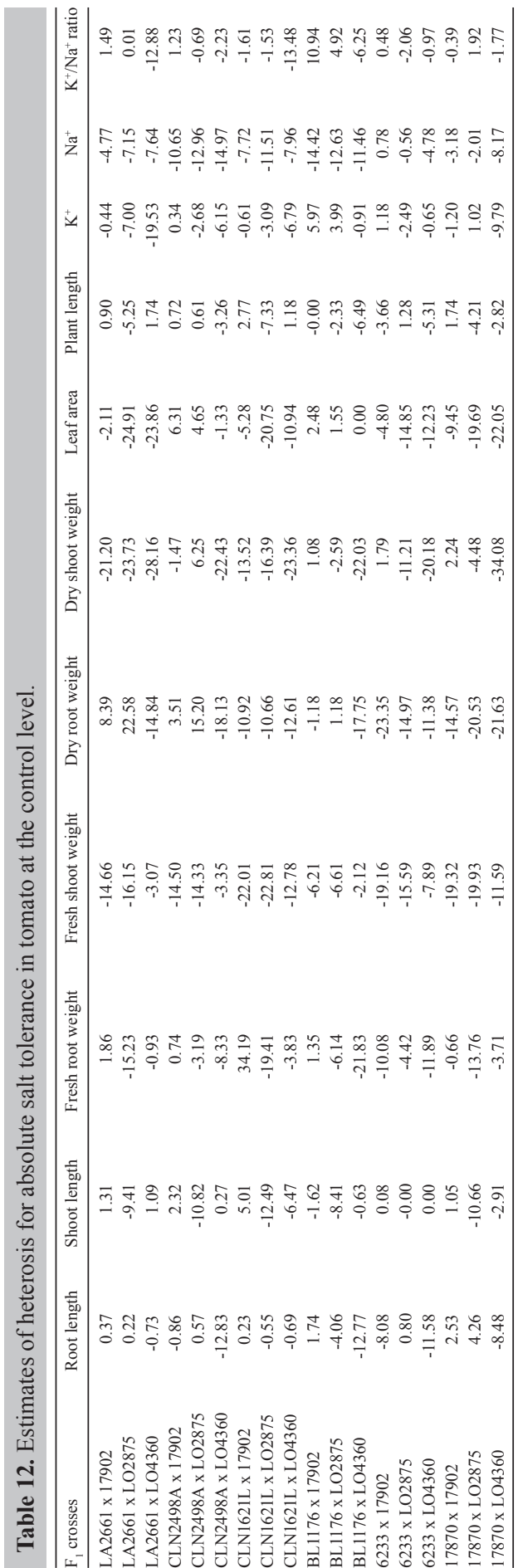




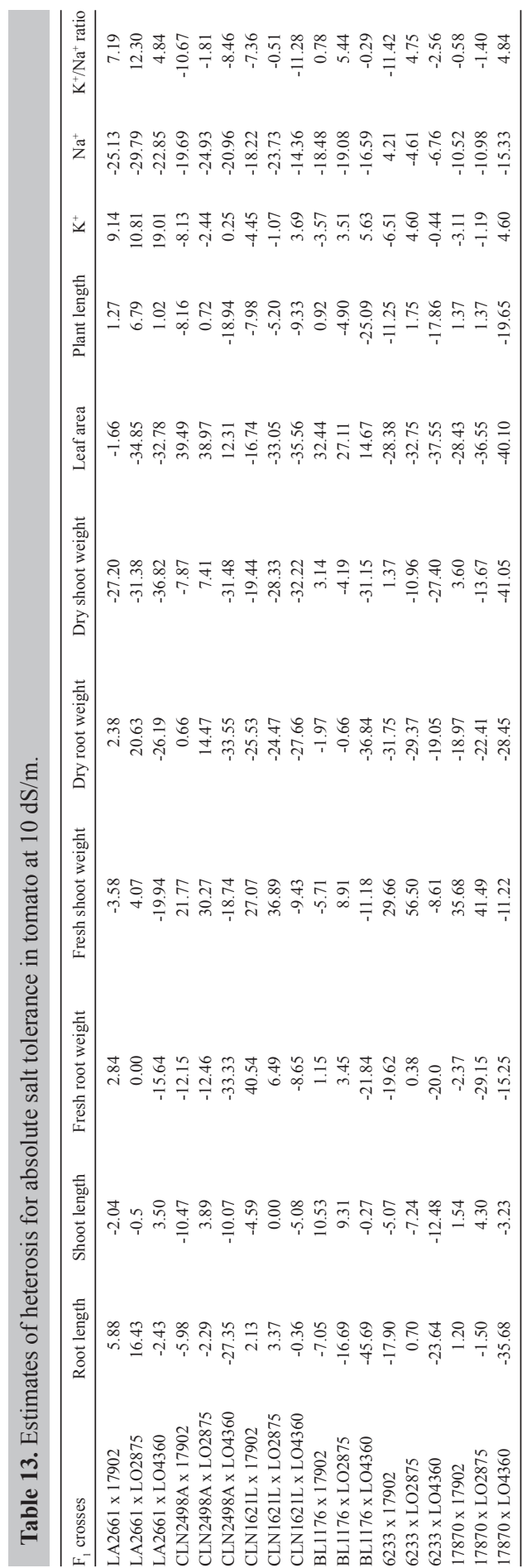


cross-combination, BL1176 x 17902 had the highest value followed by BL1176 x LO2875 and $17870 \mathrm{x}$ LO4360, respectively (Table 13). Ten hybrids exhibited significant heterosis for fresh shoot weight and maximum was observed in hybrid $6233 \times$ LO2875 followed by $17870 \times$ LO2875 and CLN1621L x LO2875. Maximum heterosis was observed in cross CLN1621L x 17902 for fresh root weight. It was observed that two and three hybrids showed significant heterosis for dry root and shoot weight, respectively, and hybrid CLN2498A x LO2875 exhibited the maximum heterosis for both traits (Table 13). For leaf area, six hybrids showed significant heterosis and hybrid CLN2498A x 17902 had the highest value followed by CLN2498A x LO2875 and BL1176 x 17902. Only one hybrid LA2661 x LO2875 showed significant heterosis for plant length. Six crosses exhibited significant heterosis for $\mathrm{K}^{+}$concentration along with $\mathrm{K}^{+} / \mathrm{Na}^{+}$ratio and high value was observed in LA2661 x LO4360 followed by LA2661 x LO2875 for $\mathrm{K}^{+}$concentration and LA2661 x LO2875 for $\mathrm{K}^{+} / \mathrm{Na}^{+}$ratio. All hybrids showed negative heterosis for all traits except the cross 6233 x 17902 (Table 13).

At high salinity stress (15 dS/m; Table 14$)$, six crosses showed significant heterosis for root length and maximum was observed in cross LA2661 x LO2875. For shoot length, significant heterosis was present in five hybrids and cross-combination CLN2498A $x$ LO2875 had the highest value for heterosis (Table 14). Maximum significant heterosis was observed for fresh root weight in cross CLN1621L x 17902, followed by 17870 x LO4360 and CLN1621L x LO2875. Of a total of 18 crosses, 11 crosses exhibited significant heterosis for fresh shoot weight and cross-combination $6233 \times$ LO2875 indicated the highest value followed by cross $6233 \times 17902$ (Table 14). In cases of dry root and shoot weight, maximum heterosis was observed in cross-combinations LA2661 x LO2875 and CLN2498A x LO2875, respectively (Table 14). For leaf area, six crosses showed significant heterosis and crosses CLN2498A x LO2875, CLN2498A x 17902 and BL1176 x LO2875 indicated the highest values. Cross-combination, LA2661 x LO2875 exhibited the highest value of significant heterosis for plant length. All crosses showed negative heterosis for $\mathrm{Na}^{+}$concentration except the cross $17870 \times$ LO2875. Six crosses showed the significant heterosis for $\mathrm{K}^{+}$concentration and $\mathrm{K}^{+} / \mathrm{Na}^{+}$ratio and maximum heterosis was observed in cross $17870 \mathrm{x}$ LO2875 followed by BL1176 x 17902.

\section{DISCUSSION}

There are several biometric methods that plant breeders use to investigate the genetics of plants. In these designs, North Carolina (Comstock and Robinson, 1952), combining ability technique (Griffing, 1956), triple test cross method (Kearsey and Jinks, 1968), diallel cross method (Hayman, 1954; Jinks, 1954), and line x tester analysis (Kempthorne, 1957) are very common in plant breeding experiments. Line $\mathrm{x}$ tester analysis is a potential biometrical tool to obtain information on the inheritance of different traits and the variation present. Therefore, it was used in the present study to obtain information on the genetic basis of variation in various physio-morphological traits of tomato grown in normal and two saline conditions.

The analysis of $F_{1}$ data showed significant variation in all the characteristics studied under normal and two salinity levels. The selection of parental lines for hybrid program was one of the objectives of this study. Thus, the estimates of GCA were calculated. A low GCA estimate indicated that the average performance of a parent in crosses does not differ from the general mean of crosses. The results obtained showed that the high GCA of a line seems to be 


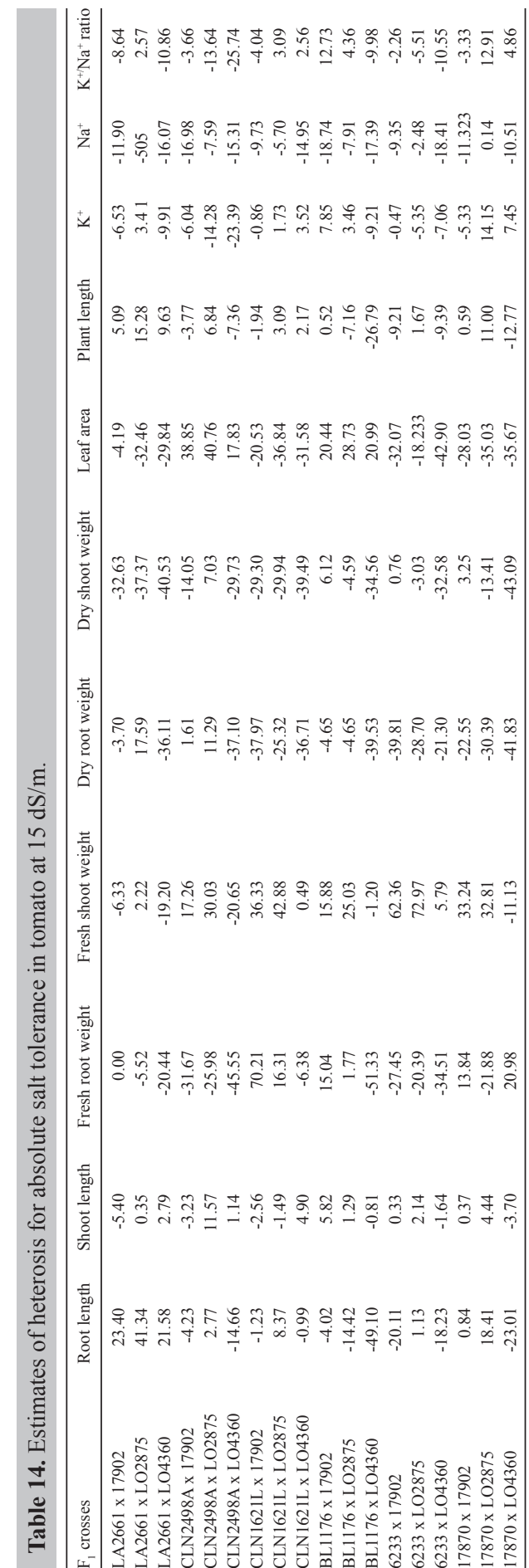


more related to the inherent genetic makeup and irrespective of the mean (Kenga et al., 2004). This showed the presence of genes with additive effects (Cruz and Regazzi, 1994). The lines having high GCA exhibited additive type of gene action and in such case selection in early generation is more effective (Roy et al., 2002).

Marília et al. (2001) reported that while selecting parent for hybrid development estimates of SCA alone are not sufficient. Along with these estimates, other information such as means and GCA of respective parents should also be taken into consideration. The hybrid having high mean and appropriate SCA and at least one parent with high GCA would certainly increase the concentration of favorable genes (Kenga et al., 2004). Moreover, these hybrids show predominance of additive genetic effects.

The hybrids having high SCA were obtained by the cross-combinations of high $\mathrm{x}$ low and high $\mathrm{x}$ high general combiners. This might be due to the interaction of dominant and recessive alleles from good and poor combiners, respectively (Roy et al., 2002). Hybrids with high SCA but both parents had low GCA exhibited the non-additive type of gene action. The best general combiners do not mean to always produce the best hybrids (Kenga et al., 2004).

There are three types of gene actions, which contributed in the inheritance of traits under saline and non-saline conditions, e.g., additive, dominance and epistatic. In low (10 dS/m) and high $(15 \mathrm{dS} / \mathrm{m})$ salinities, all traits showed non-additive type of gene action except for leaf area and $\mathrm{K}^{+}$concentration in $10 \mathrm{dS} / \mathrm{m}$, and shoot length and leaf area in $15 \mathrm{dS} / \mathrm{m}$, which exhibited additive type of gene action. Potency ratio for various traits calculated by using relative data is evident in $10 \mathrm{dS} / \mathrm{m}$ salinity stress, and non-additive type of gene action was observed for all the traits except the $\mathrm{Na}^{+}$concentration, which indicated the additive type of gene action. In high salinity stress, $15 \mathrm{dS} / \mathrm{m}$, leaf area is the only trait that showed additive type of gene action, while all other traits exhibited non-additive type of gene action. It is evident from these results that both the additive and dominance effects were significant; therefore, the genetics of salt tolerance in tomato seems highly complicated as has also been reported for some other crops, e.g., rice (Moeljopawiro and Ikehashi, 1981), grain sorghum (Ratanadilok et al., 1978; Azhar and McNeilly, 1988) and chickpea (Waheed, 1996).

Utilization of heterosis for most of the yield-related traits was credited to crosspollinated crops. However, there is evidence proving that heterosis is also present in selfpollinated crops (Freeman, 1919). Heterosis in $\mathrm{F}_{1}$ was explicit in the research conducted at seedling stage. Positive heterosis in root length and various seedlings and some physiological traits of $F_{1}$ was observed but its magnitude varied under low and high salinity, as it was substantial in control and significant in low and high salinities. The hybrid vigor, in 2-weekold roots has previously been reported in sorghum in 100 and $150 \mathrm{mM} \mathrm{NaCl}$ (Azhar et al., 1998). In the present study, the significant hybrid vigor in root length and other seedling traits of tomato under salt stress might be due to expression of genes related to salinity tolerance, as reported by Saranga et al. (1992), or might be due to the genes showing dominance effects (Paul et al., 1987). Previous studies prove that heterosis must occur for root length under non-stress and stress conditions (Ekanayake et al., 1985) and the results of the present study on salt tolerance in tomato confirmed this. Thus, our results suggest the possibility of selection for longer roots to improve salt tolerance in the species. Also, genetic studies suggested that selection for the traits, which have an additive type of gene action, should occur in early generation whereas for the traits having non-additive type of gene action, heterosis breeding is suggested in the tomato. 


\section{REFERENCES}

Allen JA, Chambers JL and Stine M (1994). Prospects for increasing the salt tolerance of forest trees: a review. Tree Physiol. 14: 843-853.

Azhar FM and McNeilly T (1988). The genetic basis of variation for salt tolerance in Sorghum bicolor (L.) moench seedlings. Plant Breed. 101: 114-121.

Azhar FM, Hussain SS and Mahmood I (1998). Heterotic response of $\mathrm{F}_{1}$ sorghum hybrids to $\mathrm{NaCl}$ salinity at early stage of plant growth. Pak. J. Sci. Ind. Res. 41: 50-53.

Comstock RE and Robinson HF (1952). Estimation of Average Dominance of Genes in Heterosis. Iowa State College Press, Ames.

Cruz CD and Regazzi AJ (1994). Modelos Biométricos Aplicados ao Melhoramento Genético. Universidade Federal de Viçosa, Imprensa Universitária, Viçosa.

Ekanayake IJ, Toole JCO, Garrity DP and Masajo DTM (1985). Inheritance of root charaters and their relation to drought resistance in rice. Crop Sci. 25: 927-932.

Falconer DS and Mackay TFC (1996). Introduction to Quantitative Genetics. Chapman and Hall, London.

Freeman GF (1919). The heredity of quantitative characters in wheat. Genetics 4: 1-93.

Gain P, Mannan MA, Pal PS, Hossain MM, et al. (2004). Effect of salinity on some yield attributes of rice. Pak. J. Biol. Sci. 7: 760-762.

Griffing B (1956). Concept of general and specific combining ability in relation to diallel crossing systems. Aust. J. Biol. Sci. 9: 463-493.

Hassan AA, Nassar HH, Barkat MA and Tolba MS (1999). Tomato breeding for salinity tolerance. III. Genetics of tolerance. Egypt. J. Hort. 26: 391-403.

Hayman BI (1954). The theory and analysis of diallel crosses. Genetics 39: 789-809.

Hollington PA (1998). Technological Breakthroughs in Screening/Breeding Wheat Varieties for Salt Tolerance. In: National Conference on "Salinity Management in Agriculture" CSSRI, Karnal.

Jinks JL (1954). The analysis of continuous variation in diallel crosses of Nicotiana rustica varieties. Genetics 39: 767-788.

Kearsey MJ and Jinks JL (1968). A general method of detecting additive, dominance and epistasic variation for biometrical traits. I. Theory. Heredity 23: 403-409.

Kempthorne O (1957). An Introduction to Genetical Statistics. John Wiley and Sons Inc., New York.

Kenga R, Alabi SO and Gupta SC (2004). Combining ability studies in tropical sorghum (Sorghum bicolor (L.) Moench). Field Crop Res. 88: 251-260.

Marília CF, Sérvio TC, Valter RO, Clibas V, et al. (2001). Combining ability for nodulation in common bean (Phaseolus vulgaris L.) genotypes from Andean and Middle American gene pools. Euphytica 118: 265-270.

Moeljopawiro S and Ikehashi H (1981). Inheritance of salt tolerance in rice. Euphytica 30: 291-300.

Munns R (2002). The Impact of Salinity Stress. Available at [http://www.plantstress.com/articles/salinity_i/salinity ihtml]. Accessed November 17, 2004.

Paul NK, Johnston TD and Eagles F (1987). Heterosis and inbreeding depression in forage rape (Brassica napus L.). Euphytica 36: 345-349.

Qureshi RH, Aslam M, Nawaz S and Mehmood T (1990). Saline Agriculture Research in Pakistan. In: Proceedings of the Indo-Pak Workshop on Soil Salinity and Water Management, PARC, Isalamabad, 409-423.

Qureshi RH (1993). Alternative Strategies for Tackling the Soil Salinity Problem. Department of Soil Science, University of Agriculture, Faisalabad.

Ratanadilok N, Maracarian A and Schmilzel C (1978). Salt tolerance in grain sorghum. Agron. Abstr. 70: 160.

Rausch T, Kirsch M, Low R, Lehr A, et al. (1996). Salt stress responses of higher plants: the role of proton pumps and $\mathrm{Na}^{+} /$ $\mathrm{H}^{+}$antiporters. J. Plant Physiol. 148: 425-433.

Roy NC, Jettopujov VN and Solanik NM (2002). Combining ability for some agronomic characters in alfalfa (Medicago sativa L). Pak. J. Agr. Res. 17: 346-350.

Saranga Y, Cahaner A, Zamir D, Marani A, et al. (1992). Breeding tomatoes for salt tolerance: inheritance of salt tolerance and related traits in interspecific populations. Theor. Appl. Genet. 84: 390-396.

Sarwar G, Ashraf MY and Naeem M (2003). Genetic variability of some primitive bread wheat varieties to salt tolerance. Pak. J. Bot. 35: 771-777.

Shaaban MM, El-Fouly MM, Zanaty EL, El-Nour AAA, et al. (2004). Halophytes and foliar fertilization as a useful technique for growing processing tomatoes in the saline affected soils. Pak. J. Biol. Sci. 7: 503-507.

Steel RGD, Torrie JH and Dickay DA (1997). Principles and Procedures of Statistics, a Biometrical Approach. McGraw Hill Book Co., New York. 
Waheed A (1996). Development of Salt Tolerance in Chickpea (Cicer arietinum L.) and Lentil (Lens culinaris medic). Ph.D. thesis, Institute of Pure and Applied Biology, Department of Botany, Bahuddin Zakaryai University, Multan.

Winicov I (1998). New molecular approaches to improving salt tolerance in crop plants. Ann. Bot. 82: 703-710.

Wynne JC, Enery DA and Rice PH (1970). Combining ability estimation in Arachis hypogaea L. II. Field performance of $\mathrm{F}_{1}$ hybrids. Crop Sci. 10: 713-715. 